\title{
Disentangling Post-Fire Logging and High-Severity Fire Effects for Spotted Owls
}

\author{
Chad T. Hanson ${ }^{1, *}$, Derek E. Lee ${ }^{2}$ (D) and Monica L. Bond ${ }^{3}$ \\ 1 Earth Island Institute, 2150 Allston Way, Suite \#460, Berkeley, CA 94704, USA \\ 2208 Mueller Laboratory, Biology Department, Pennsylvania State University, University Park, PA 16802, USA; \\ dereklee@psu.edu \\ 3 Wild Nature Institute, 15 North Main Street \#208, Concord, NH 03301, USA; monica@wildnatureinstitute.org \\ * Correspondence: cthanson1@gmail.com
}

check for

updates

Citation: Hanson, C.T.; Lee, D.E.; Bond, M.L. Disentangling Post-Fire Logging and High-Severity Fire Effects for Spotted Owls. Birds 2021, 2, 147-157. https://doi.org/ 10.3390/birds2020011

Academic Editor: Jukka Jokimäki

Received: 25 March 2021

Accepted: 12 April 2021

Published: 14 April 2021

Publisher's Note: MDPI stays neutral with regard to jurisdictional claims in published maps and institutional affiliations.

Copyright: (c) 2021 by the authors. Licensee MDPI, Basel, Switzerland. This article is an open access article distributed under the terms and conditions of the Creative Commons Attribution (CC BY) license (https:/ / creativecommons.org/licenses/by/ $4.0 /)$.
Simple Summary: High-severity fire transforms Western U.S. conifer forests into a unique forest type known as "snag forest habitat", which Spotted Owls actively use to hunt for small mammal prey. This snag forest habitat is heavily targeted by post-fire logging projects. Studies have shown that post-fire logging significantly reduces Spotted Owl occupancy, but efforts have generally not been made to separate the effects of such logging from the influence of high-severity fire alone on Spotted Owls. We document that articles reporting negative effects of high-severity fire on Spotted Owls were pervasively confounded by post-fire logging. Our results indicate a need to approach analyses of high-severity fire and Spotted Owls differently in future research.

\begin{abstract}
The Spotted Owl is a rare and declining raptor inhabiting low/middle-elevation forests of the Pacific Northwest, California, and the Southwest in the USA. It is well established that Spotted Owls select dense, mature, or old forests for nesting and roosting. High-severity fire transforms such forests into a unique forest type known as "snag forest habitat", which the owls select for foraging. This habitat is disproportionately targeted by post-fire logging projects. Numerous recent articles have explored the influence of high-severity fire and post-fire logging on this species. Studies have shown that post-fire logging significantly reduces Spotted Owl occupancy, but efforts have generally not been made to disentangle the effects of such logging from the influence of high-severity fire alone on Spotted Owls. We conducted an assessment of published, peer-reviewed articles reporting adverse impacts of high-severity fire on Spotted Owls, exploring the extent to which there may have been confounding factors, such as post-fire logging. We found that articles reporting adverse impacts of high-severity fire on Spotted Owls were pervasively confounded by post-fire logging, and in some cases by a methodological bias. Our results indicate a need to approach analyses of high-severity fire and Spotted Owls differently in future research.
\end{abstract}

Keywords: Strix occidentalis; wildfire; post-fire logging; salvage logging; forests

\section{Introduction}

Patches of high-severity fire, in which most or all trees are killed [1], are a natural component of mixed-conifer and mixed-evergreen forest types commonly inhabited by the Spotted Owl (Strix occidentalis) across most of its range, including the Eastern Cascades, Klamath-Siskiyou region of Northwestern California, the Sierra Nevada, and the Southwestern USA [2-7]. The Spotted Owl is one of the most-studied raptors in the world, with decades of intensive research [8]. Populations have been declining in managed forests that were largely unaffected by recent wildfires $[9,10]$ while remaining stable in unmanaged forests that experienced large fires [11]. Despite this, it remains a commonly held belief that large fires are a primary threat [12].

It is well documented that Spotted Owls select stands of dense, mature, or old forest for nesting and roosting $[13,14]$. High-severity fire transforms such stands into "snag forest 
habitat", also known as "complex early seral forest" [15], immediately after fire. Complex early seral snag forests contain many standing fire-killed trees, coarse woody debris, and regrowing shrubs and seedlings, which provide habitat for many fire-adapted taxa [15]. Spotted Owls have been found to actively use snag forest habitat areas for foraging from one to more than 12 years post-fire [16-19], likely due to an ample small mammal prey base [20], which can be 2-6 times greater in such post-fire habitat compared to unburned old forest [21]. Conversely, post-fire logging has been found to adversely affect Spotted Owl occupancy and reproduction, by removing and degrading the snag forest habitat used by the owl's prey species and by removing nearly all the snags that Spotted Owls depend upon as a "perch and pounce" predator [22,23]. Seemingly minor amounts of post-fire logging (as little as 5\%) significantly reduce Spotted Owl occupancy [22]. Although the complex, but generally neutral or positive, effects of high-severity fire for Spotted Owls is established [23,24], debate remains about the extent to which factors such as post-fire logging may confound attempts to better understand effects of high-severity fire [22].

In November of 2019, the U.S. Fish and Wildlife Service denied a petition to list the California Spotted Owl subspecies (S. o. occidentalis) as threatened under the Endangered Species Act, asserting that high-severity fire is the primary threat to the owl [12]. The decision did not mention post-fire logging as a threat, and encouraged increased logging of all types ostensibly to curb high-severity fire. The decision also did not address research that found increased logging, including post-fire logging, is often associated with higher, not lower, fire severity in subsequent wildland fires [25-28].

Here, we investigate published articles that have reported adverse effects of highseverity fire on Spotted Owls, exploring the extent to which confounding factors such as post-fire logging may have affected results and conclusions. This information has important implications for forest management that impacts populations of this imperiled raptor.

\section{Materials and Methods}

For our evaluation of the extent to which confounding effects, such as post-fire logging, have occurred in existing studies on high-severity fire, we assessed all articles reporting adverse effects of forest fire on Spotted Owls. The search encompassed articles on all three subspecies, the northern Spotted Owl (S. o. caurina), California Spotted Owl, and Mexican Spotted Owl (S. o. lucida), inhabiting low/middle-elevation conifer forests in the Pacific Northwest, California, and the Southwestern USA.

Our approach was to conduct a literature search for all peer-reviewed, published articles that reported one or more adverse impacts from high-severity fire on Spotted Owl occupancy, survival, reproduction, recruitment, or foraging. We first queried the Google Scholar database using the keywords "high severity fire" and "Spotted Owl" to find any suitable articles. We then evaluated each article to determine whether a confounding influence, including post-fire logging, was present in the analysis of high-severity fire effects. We extracted and tabulated data from each paper regarding: subspecies, location, number of burned breeding sites, occurrence of post-fire logging in the study area (yes or no), whether logging and fire were conflated (yes or no), whether distance from breeding site center was included in foraging selection analysis (yes or no), the type of effect, and whether there was a statistically significant $(\alpha=0.05)$ high-severity fire or post-fire logging effect (positive $=+$, no effect $=0$, and negative $=-$ ). In our assessment, we did not include review papers without primary data, nor did we include papers with anecdotal references to wildland fire effects on Spotted Owls.

\section{Results}

We found 13 published articles reporting adverse high-severity fire effects on Spotted Owls (Table 1). Every study that showed a significant negative effect of "high-severity fire" was also confounded by post-fire logging, except for one study [29] that was not confounded by post-fire logging within the nest core but could have been influenced by post-fire logging outside the core [22]. 


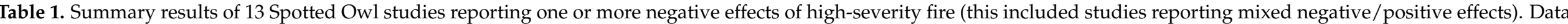

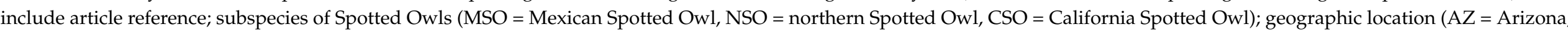

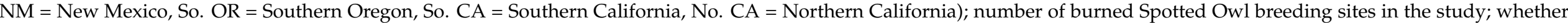

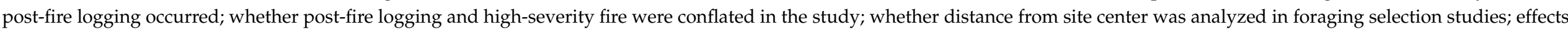
analyzed; statistically significant result as stated in the article $(0=$ no effect,$+=$ positive effect, $-=$ negative effect $)$.

\begin{tabular}{|c|c|c|c|c|c|c|c|c|}
\hline Reference & Subspecies & Location & $\begin{array}{c}\text { Number of } \\
\text { Burned Owl Sites }\end{array}$ & $\begin{array}{l}\text { Post-Fire Logging } \\
\text { in Severe Burns? }\end{array}$ & $\begin{array}{l}\text { Logging and Severe } \\
\text { Fire Conflated? }\end{array}$ & $\begin{array}{l}\text { Distance from Site } \\
\text { Center Analyzed? }\end{array}$ & $\begin{array}{l}\text { Effect(s) } \\
\text { Analyzed }\end{array}$ & Stated Effect \\
\hline Jenness et al., 2004 & MSO & $\mathrm{AZ}, \mathrm{NM}$ & 33 & Yes & No & $\mathrm{Na}$ & Occupancy & 0 \\
\hline Clark et al., 2011 & NSO & So. OR & 11 & Yes & Yes & $\mathrm{Na}$ & Survival & 0 \\
\hline Lee et al., 2013 & $\mathrm{CSO}$ & So. CA & 71 & Yes & No & $\mathrm{Na}$ & Occupancy & 0 \\
\hline Tempel et al., 2014 & $\mathrm{CSO}$ & Sierra Nevada & 12 & Yes & Yes & $\mathrm{Na}$ & Occupancy & inestimable \\
\hline Lee and Bond 2015a & $\mathrm{CSO}$ & So. CA & 71 & Yes & No & $\mathrm{Na}$ & Occupancy & - \\
\hline Lee and Bond 2015a & $\mathrm{CSO}$ & So. CA & 71 & Yes & No & $\mathrm{Na}$ & Reproduction & 0 \\
\hline Jones et al., 2016 & $\mathrm{CSO}$ & $\begin{array}{l}\text { Sierra } \\
\text { Nevada }\end{array}$ & 30 & Yes & Yes & $\mathrm{Na}$ & Occupancy & - \\
\hline Jones et al., 2016 & $\mathrm{CSO}$ & $\begin{array}{c}\text { Sierra } \\
\text { Nevada }\end{array}$ & 9 & Yes & Yes & No & Foraging & - \\
\hline Eyes et al., 2017 & $\mathrm{CSO}$ & $\begin{array}{c}\text { Sierra } \\
\text { Nevada }\end{array}$ & 13 & No & No & No & Foraging & 0 \\
\hline Rockweit et al., 2017 & NSO & No. CA & 24 & Yes & Yes & $\mathrm{Na}$ & Survival & - \\
\hline Rockweit et al., 2017 & NSO & No. CA & 24 & Yes & Yes & $\mathrm{Na}$ & Recruitment & + \\
\hline Jones et al., 2020a & $\mathrm{CSO}$ & $\begin{array}{c}\text { Sierra } \\
\text { Nevada }\end{array}$ & 23 & Yes & No & Yes & Foraging & 0 \\
\hline Schofield et al., 2020 & $\mathrm{CSO}$ & $\begin{array}{l}\text { Sierra } \\
\text { Nevada }\end{array}$ & 12 & No & No & $\mathrm{Na}$ & Occupancy & 0 \\
\hline Kramer et al., 2021 & $\mathrm{CSO}$ & $\begin{array}{c}\text { Sierra } \\
\text { Nevada }\end{array}$ & 22 & No & No & No & Foraging & 0 \\
\hline
\end{tabular}


Below we provide further details about each of the studies.

Jenness et al. (2004) [30] — this study reported no significant effect of fire on occupancy and reproduction of Mexican Spotted Owls in fire areas relative to unburned forests in Southwestern USA. They described a statistically non-significant adverse impact $(p=0.11)$ and attributed this to high-severity fire. Bond (2016) [31] reported that post-fire logging was minor in most of the fire areas in this study. The amount of post-fire logging was not quantified.

Clark et al. (2011) [32] and Clark et al. (2013) [33] —investigating post-fire survival of northern Spotted Owls in the Quartz and Timbered Rock fires on Southwestern Oregon [32], and post-fire occupancy of northern Spotted Owls in the Quartz, Timbered Rock, and Biscuit fires of Southwestern Oregon [33], these studies reported adverse impacts on Spotted Owls from the combined effects of high-severity fire and post-fire logging. In both studies, the area of high-severity fire and post-fire logging were included as a single variable and their effects were therefore conflated.

Lee et al. (2013) [34] — for fire areas in the San Bernardino and San Jacinto Mountains of Southern California, this study reported lower California Spotted Owl site occupancy with higher levels of high-severity fire and post-fire logging. Both variables were included and analyzed independently. The $95 \%$ confidence intervals of beta coefficients for all fire and post-fire logging effects overlapped zero indicating the effects were not statistically significant. The analysis examined habitat variables only within the 203-ha nesting core area and did not include impacts from post-fire logging outside these innermost core areas.

Tempel et al. (2014) [35] — this study reported reduced California Spotted Owl site colonization due to high-severity fire, based on four owl sites in the 2001 Star fire in the central Sierra Nevada. However, nearly all of the high-severity fire areas in these four owl sites were post-fire logged shortly after the Star fire occurred [22].

Lee and Bond (2015a) [29] — this study found previous occupancy state (reproductive or not) was an important predictor of occupancy within a California Spotted Owl site's 203-ha site in the San Bernardino and San Jacinto Mountains of Southern California. Highseverity fire and post-fire logging covariates were both negatively correlated with the probability of site occupancy. The occupancy of sites that supported reproductive owls the previous year was reduced 0.02 by high-severity fire and 0.03 by post-fire logging. The occupancy of sites that supported non-reproductive owls the previous year was reduced by 0.19 by severe fire and 0.26 by post-fire logging. Neither high-severity fire nor post-fire logging significantly influenced reproduction. The analysis examined habitat variables only within the 203-ha nesting core area and did not include impacts from post-fire logging outside these innermost core areas.

Comfort et al. (2016) [36] —in a radio-telemetry study of northern Spotted Owl foraging in the 2002 Timbered Rock fire in Southwestern Oregon, the owls generally avoided "hard edges" defined as abrupt changes in fire severity. The study noted that post-fire logging had been extensive and pervasive in the high-severity fire areas in the Timbered Rock fire and that hard edges tended to result from logging, and their analysis did not distinguish between unlogged high-severity fire areas and post-fire logged sites. Therefore we considered this study as showing adverse effects of post-fire logging.

Jones et al. (2016) [37] — this study investigated the effect of the King fire of 2014 in the central Sierra Nevada on California Spotted Owl occupancy and foraging. The study reported reduced occupancy in sites with $>50 \%$ high-severity fire, and a pattern of avoidance of high-severity fire areas for foraging. The authors stated that some post-fire logging had occurred but described it as inconsequential $(<5 \%)$. A subsequent quantitative assessment showed that a mean of $12 \%$ of the area within Spotted Owl sites in the King fire had been post-fire logged-higher than the level (5\%) above which significant reductions in occupancy occur [22].

The foraging analysis in Jones et al. (2016) did not distinguish between snag forest habitat (high-severity fire occurring in mature forest, with no post-fire logging) versus 
high-severity fire areas in pre-fire clearcuts (young plantations), or high-severity fire areas that had been post-fire logged. Therefore the foraging analysis was confounded by both pre-fire clearcutting and post-fire logging [22].

A further problem is that Jones et al. (2016) did not analyze use of high-severity fire areas as a function of distance from Spotted Owl site centers. Spotted Owls have a higher probability of foraging in stands nearest to site centers [16,17,38-44]. Differential availability of high-severity fire areas near site centers created a bias in foraging habitat selection results because the effect of distance was not explicitly analyzed.

Eyes et al. (2017) [18] — this study reported a mix of non-significant positive and negative effects on California Spotted Owl foraging in high-severity fire areas in the absence of post-fire logging. Eyes et al. (2017) found that the odds of Spotted Owls using "high contrast edges" created by high-severity fire for foraging "were 2.8 times greater than odds for the low contrast edge type and 3.5 times greater than for the no edge type". The authors reported a reduction (4\%) in the probability of use from the lowest to the highest fire severity index, but there was nearly equivalent evidence (weight) for models that had no fire effect relative to models that included a fire effect. However, Eyes et al. did not analyze the interaction of distance with fire severity.

Figure 1 of Eyes et al. shows that, in most of the owl sites analyzed by the authors, high-severity fire patches were several hundred meters to $>1 \mathrm{~km}$ from site centers. In the three Spotted Owl sites in Eyes et al. for which the owls had access to high-severity fire areas in reasonable proximity to site centers, the owls actively foraged in the high-severity fire patches (Eyes et al. 2017).

Moreover, Eyes et al. under-reported foraging in snag forest habitat created by highseverity fire in two of these three territories. Numerous foraging locations were in highseverity fire patches created by an earlier fire (the 1990 A-Rock fire) that subsequently reburned at low/moderate-severity (compare Figure 1 of Eyes et al. 2017 with Figure 2 of van Wagtendonk and Lutz 2007 [45]) within 19 years or less after the 1990 fire, and decades before natural succession would transition the snag forest habitat into mid-successional forest [46].

Rockweit et al. (2017) [47] — this study reported mixed significant positive and negative effects of various proportions of high-severity fire on vital rates, with some reduced survival and some increased recruitment in burned northern Spotted Owl territories in several fires in Northwestern California. The negative results regarding high-severity fire stemmed from three owl sites in a single fire, the Sims fire of 2004. Rockweit et al. (2017) did not mention that post-fire logging had occurred in their study area, but the high-severity fire areas in the three Spotted Owl territories they studied in the Sims fire were in fact heavily post-fire logged, based on 2006 satellite imagery (http:/ /johnmuirproject.org/wpcontent/uploads /2019/03/SateliteImagesANDRockweit2017etalFigure.pdf, accessed on: 13 April 2021).

If territory fitness (apparent survival + recruitment) reflects habitat quality for northern Spotted Owl territories, Rockweit et al. (2017) indicates that $36 \%$ of territories analyzed showed no fitness consequences, $14 \%$ showed decreased fitness, and $50 \%$ showed increased fitness after being burned. Thus, high-severity fire resulted in more benefits than costs to northern Spotted Owls, which might have been even more evident if Rockweit et al. had accounted for post-fire logging in the Sims fire.

Jones et al. (2020a) [19] — this study reported that, in the King fire, California Spotted Owls avoided post-fire logged areas, and selected high-severity fire patches where the average patch size was up to 115 ha, but avoided making "deep forays" into larger highseverity fire patches. One important limitation of this study is the fact that most of the post-fire salvage logging that had occurred by the time they conducted their research (2015-2017) was not included in their analysis. This is illustrated by comparing Figure 1 of Jones et al. (2020a) to Figure 3 of DellaSala et al. (2017) [48]. The omitted areas of postfire logging were almost entirely within the largest high-severity fire patches. Therefore, the conclusions in Jones et al. (2020a) regarding large high-severity fire patches were- 
similar to their earlier study in the same fire-confounded by post-fire logging that was not fully accounted for in their analysis. Additionally, in their analysis of Spotted Owl selection/avoidance of high-severity fire patches, Jones et al. (2020a) did not exclude recent numerous pre-fire clearcuts that burned at high severity in the King fire [22]. As a result, their analysis of selection/avoidance of high-severity fire areas was not specific to snag forest habitat but, rather, was confounded by extensive pre-fire and post-fire clearcutting.

Schofield et al. (2020) [11] — this study investigated California Spotted Owl occupancy before and after the Rim fire of 2013 in Yosemite National Park within areas protected from logging (no pre-fire or post-fire logging). They found 11 occupied Spotted Owl territories during a ten-year survey period before the Rim fire (2004-2013) and 12 occupied territories during a three-year survey period in the same area after the Rim fire (Schofield et al. 2020, Figure 1). Based on this, the authors concluded that, in these areas that were not subjected to post-fire logging, this large mixed-intensity fire did not adversely affect Spotted Owl occupancy.

Schofield et al. also assessed the percent high-severity fire within the 153-ha nest core, and found that all of the sites occupied after the Rim fire had $<30 \%$ high-severity fire within nest cores, which might be perceived as a negative effect of large areas of severe fire.

Kramer et al. (2021) [49] — the authors of this study investigated foraging habitat selection of California Spotted Owls in mixed-severity fire areas in three national parks (no pre- or post-fire logging). Kramer et al. (2021) found that Spotted Owls neither selected nor avoided high-severity fire patches overall, and reported reduced use of the largest high-severity fire patches. The findings of Kramer et al. (2021) were confounded by the fact that they did not analyze use of resources as a function of distance from Spotted Owl site centers (no analysis of distance), which creates a bias since Spotted Owls are central-place foragers and select lower-severity areas for their nest cores.

\section{Discussion}

\subsection{General Observations}

We found that articles reporting adverse impacts of high-severity fire on Spotted Owls are widely confounded by reported and unreported post-fire logging. Two articles $[18,49]$ did not have post-fire logging because they occurred in national parks, but were problematic for a different reason-a failure to analyze distance from site center in foraging habitat selection. One study that did explicitly disentangle fire and post-fire logging effects found adverse effects of both types of disturbances on California Spotted Owls [29], but was conducted in one region, Southern California, where owl sites had substantially lower amounts of suitable old-forest habitat before fire compared with owl sites in other regions, and post-fire logging had occurred outside of the nest core areas analyzed [22]. This suggests that studies should analyze effects of post-fire logging at a larger scale around owl core areas.

We did not include in our assessment anecdotal published reports, such as the brief mention in Gutiérrez and Pritchard (1990) [50] that they did not find Spotted Owls in a 1987 fire area west of Palomar Mountain in Southern California. Notably, however, the first available post-fire satellite imagery following this 1987 fire, taken in 1994 and 1995, reveals logging roads, landings, skid trails, and cleared areas consistent with post-fire logging in numerous areas northwest, west, and southwest of Palomar Mountain, but no data were provided on pre-fire owl locations in the fire area [50]. Additionally, we did not include published reports or presentations that were not subjected to the peer-review process, such as Gaines et al. (1997) [51], King et al. (1998) [52], and Keane et al. (2010) [53]. However, King et al. (1998) discussed extensive post-fire logging in their study area, and though Gaines et al. (1998) and Keane et al. (2010) did not specifically mention post-fire logging, subsequent research documented that widespread post-fire logging had indeed occurred in both study areas by the time of surveys [22,54].

In the absence of post-fire logging-or prior to post-fire logging-in the Sierra Nevada, Spotted Owl occupancy has been found to be high, and often increasing, in fire areas 
with substantial high-severity fire effects [22,55], including in very large forest fires [11,56]. However, high-severity fire and post-fire logging are pervasively entangled in existing scientific literature regarding Spotted Owls. In this context, federal wildlife and land managers are using existing confounded studies to promote the view that only highseverity fire, not post-fire logging, is a threat to Spotted Owls and, ironically, are promoting increased post-fire logging and tree plantation establishment in Spotted Owl habitat on public lands ostensibly to curb future fires [12,57]. This is in stark contrast to research finding that such management not only harms Spotted Owls [22,23] but also tends to increase future fire severity $[25,27]$. This suggests a need for more rigorous efforts to be made in future research and forest management decisions to disentangle the impacts of post-fire logging from the effects of high-severity fire.

Several rebuttals have been published attempting to counter findings that post-fire logging was harmful to Spotted Owls. However, these rebuttals also failed to properly disentangle post-fire logging from severe fire effects. For example, Jones et al. (2019) [58] presented a critique of Hanson et al. (2018) [22], which found a large adverse impact of post-fire logging on California Spotted Owl occupancy, but no effect of high-severity fire when sites without the confounding effect of post-fire logging were analyzed. Hanson et al. (2018) was based on data from eight fire areas in California, including the King fire of 2014 in the Sierra Nevada. Jones et al. did not dispute the main finding of Hanson et al., that post-fire logging adversely affects Spotted Owl occupancy, nor did Jones et al. dispute the data from Hanson et al. for seven of the eight fire areas studied. Rather, Jones et al. focused on a small subset of owl sites in a single fire, the King fire.

The authors criticized Hanson et al. for excluding four Spotted Owl sites with $>80 \%$ high-severity fire in the King fire, speculating that the inclusion of these four sites (PLA050, PLA065, PLA067, and PLA113) would have shown "a negative effect of high-severity fire" on Spotted Owl occupancy, since all four of them were unoccupied in the year after the King fire. However, all four of these sites had been post-fire logged, with an average of $22 \%$ post-fire logging per site. Therefore, these sites could not have been included in the Hanson et al. analysis of high-severity fire effects, since that analysis explicitly pertained to sites without the confounding influence of post-fire logging.

Hanson et al. (2018) [22] pointed out that Jones et al. (2016) [37] did not analyze distance from the center of Spotted Owl sites in their foraging habitat selection analysis, and that this created a methodological bias against high-severity fire locations, as discussed above regarding Eyes et al. (2017) [18] and Kramer et al. (2021) [49]. In response, Jones et al. (2019) [58] note that they excluded the farthest $5 \%$ of foraging locations in Jones et al. (2016) [37]. However, this does not remedy the methodological bias against high-severity fire locations. Analyzing foraging habitat selection as a function of distance means that distance from the center is a covariate of every available and used habitat element [16]. The farthest locations are an important part of the dataset when distance from the site center is specifically incorporated into resource selection analyses, and should not have been excluded.

For instance, of the nine Spotted Owls that Jones et al. (2016) [37] chose for their foraging habitat selection, seven of these have site centers that were approximately 1100 3000 meters from the nearest edge of large tracts of high-severity fire, based on Figure 3 of Jones et al. (2016) [37]. Given that Jones et al. (2016) used an 1100-meter radius around site centers to spatially define Spotted Owl territories, Jones et al. (2019)'s assertion that these Spotted Owls were avoiding the large high-severity fire tracts would be the same as assuming the owls were avoiding unburned old forests 1100-3000 meters away from the site centers in the opposite direction of the King fire.

\subsection{Observations on Opposing Studies}

Peery et al. (2019) [59] also mentioned that Hanson et al. (2018) [22] excluded four owl sites in the King fire with $>80 \%$ high-severity fire from the analysis of high-severity fire effects, and suggested that these sites indicated negative impacts of high-severity fire 
on Spotted Owl occupancy. As discussed above regarding Jones et al. (2019) [58], the fundamental purpose of the high-severity fire analysis in Hanson et al. (2018) was to avoid the confounding effect of post-fire logging, which is why this analysis was restricted to sites with $<5 \%$ post-fire logging. None of the four King fire sites noted by Peery et al. (2019) met that criterion; all had substantial post-fire logging, as discussed above. Therefore, the exclusion of these sites from the high-severity fire analysis in Hanson et al. (2018) was specifically oriented toward avoiding bias in the findings.

Peery et al. (2019) further questioned whether Hanson et al. (2018) [22] mistakenly characterized the occupancy status of two Spotted Owl sites (PLA039 and PLA065) in the King fire. Specifically, Peery et al. stated that one of these sites, PLA039, should not be considered as occupied after the fire due to its proximity to site PLA080. However, this is inconsistent with the methods of Jones et al. (2016) [37], who defined site occupancy as one or more Spotted Owl detections occurring in a given site in a given year. Hanson et al. (2018) [22] followed the same approach as Jones et al. (2016) [37]. The pre-fire (2014) Spotted Owl occupancy data for the King fire from the U.S. Forest Service show that both PLA039 and PLA080 were occupied before the King fire, and the Forest Service data also show that detections occurred in both PLA039 and PLA080 in 2015 (http:/ /johnmuirproject.org/wpcontent/uploads/2019/03/USFSKingFireCalSpottedOwlOccupancyData.pdf, accessed on: 13 April 2021). Similarly, Peery et al. asserted that one of the post-fire logged sites, PLA065, was occupied in 2014, and that Hanson et al. (2018) should have included it in the analysis, however the same U.S. Forest Service data shows this site as unoccupied in 2014.

Finally, Jones et al. (2020b) [60] offered a comment on Lee (2018) [23], a meta-analysis of the effects of mixed-severity fires, and high-severity fire in particular, on Spotted Owls. Jones et al. (2020b) agreed with the most central findings and conclusions from Lee (2018) [23], including: (a) western U.S. forests burned in mixed-severity fires historically, and also currently, and such fires include a high-severity fire component; (b) high-severity fire has not resulted in range-wide declines in Spotted Owl populations; and (c) highseverity fire has not been an overriding driver of recently observed long-term Spotted Owl population declines.

However, Jones et al. (2020b) [60] questioned the results of the meta-analysis, raising several methodological questions and critiques, some of which were also raised in Peery et al. (2019) [59], and arguing that negative effects of high-severity fire might possibly emerge if the data were analyzed differently. In response, Lee (2020) [24] reanalyzed the data according to their suggestions and found that the original results and conclusions in Lee (2018) [23] were robust to Peery et al.'s technical criticisms. Notably, removing studies confounded by post-fire logging resulted in an overall positive effect of mixed-severity fires on Spotted Owl occupancy, and increasing percentage of high-severity fire was associated with increased Spotted Owl reproduction.

\section{Management Implications}

Based on the current state of knowledge indicating significant adverse effects of post-fire logging on this imperiled forest raptor, we recommend that post-fire logging be avoided within at least a 2000-m radius around Spotted Owl site centers. If we are to better understand the response of Spotted Owls to high levels of high-severity fire, and make forest management and wildlife protection decisions based on evidence rather than assumptions, we must investigate this issue without the confounding effect of postfire logging. Further, we recommend that future research funded by land management agencies regarding high-severity fire effects on Spotted Owls exclude sites with $>5 \%$ postfire logging within a 2000-m radius of the site center (see Hanson et al. 2018). Third, we recommend that such future research always analyze distance from site center as a covariate when Spotted Owl habitat selection is being analyzed with regard to fire severity, and that foraging habitat analyses separate pre-fire and post-fire clearcut areas that burned at high-severity from snag forest habitat created by high-severity fire in mature/old forest. 
Author Contributions: Conceptualization, C.T.H., D.E.L., and M.L.B.; methodology, C.T.H., D.E.L., and M.L.B.; validation, C.T.H., D.E.L., and M.L.B.; formal analysis, C.T.H., D.E.L., and M.L.B.; investigation, C.T.H., D.E.L., and M.L.B.; resources, C.T.H., D.E.L., and M.L.B.; data curation, C.T.H., D.E.L., and M.L.B.; writing-original draft preparation, C.T.H.; writing-review and editing, C.T.H., D.E.L., and M.L.B.; visualization, C.T.H., D.E.L., and M.L.B.; supervision, C.T.H.; project administration, C.T.H.; funding acquisition, C.T.H.. All authors have read and agreed to the published version of the manuscript.

Funding: This research was funded by Environment Now Foundation, grant number 2020 to C.T. Hanson.

Institutional Review Board Statement: Not applicable.

Informed Consent Statement: Not applicable.

Data Availability Statement: All studies analyzed in this review are available online.

Acknowledgments: We thank Environment Now Foundation for providing support to Chad T. Hanson. We also thank the two reviewers for their thoughtful comments, which improved this manuscript.

Conflicts of Interest: The authors declare no conflict of interest. The funder had no role in the design of the study; in the collection, analyses, or interpretation of data; in the writing of the manuscript, or in the decision to publish the results.

\section{References}

1. Miller, J.D.; Thode, A.E. Quantifying burn severity in a heterogeneous landscape with a relative version of the delta Normalized Burn Ratio (dNBR). Remote Sens. Environ. 2007, 109, 66-80. [CrossRef]

2. Mallek, C.; Safford, H.; Viers, J.; Miller, J. Modern departures in fire severity and area vary by forest type, Sierra Nevada and southern Cascades, USA. Ecosphere 2013, 4, 153. [CrossRef]

3. Baker, W.L. Historical forest structure and fire in Sierran mixed-conifer forests reconstructed from General Land Office survey data. Ecosphere 2014, 5, 79. [CrossRef]

4. Odion, D.C.; Hanson, C.T.; Arsenault, A.; Baker, W.L.; DellaSala, D.A.; Hutto, R.L.; Klenner, W.; Moritz, M.A.; Sherriff, R.L.; Veblen, T.T.; et al. Examining historical and current mixed-severity fire regimes in ponderosa pine and mixed-conifer forests of western North America. PLoS ONE 2014, 9, e87852. [CrossRef]

5. DellaSala, D.A.; Hanson, C.T. (Eds.) The Ecological Importance of Mixed-Severity Fires: Nature's Phoenix; Elsevier Inc.: Waltham, MA, USA, 2015.

6. Doerr, S.H.; Santín, C. Global trends in wildfire and its impacts: Perceptions versus realities in a changing world. Philos. Trans. R. Soc. B 2016, 371, 20150345. [CrossRef]

7. Baker, W.L.; Hanson, C.T. Improving the use of early timber inventories in reconstructing historical dry forests and fire in the western United States. Ecosphere 2017, 8, e01935. [CrossRef]

8. Gutiérrez, R.J. Spotted owl research: A quarter century of contributions to education, ornithology, ecology, and wildlife management. Condor 2008, 110, 792-798. [CrossRef]

9. Conner, M.M.; Keane, J.J.; Gallagher, C.V.; Jehle, G.; Munton, T.E.; Shaklee, P.A.; Gerrard, R.A. Realized population change for long-term monitoring: California Spotted Owl case study. J. Wildl. Manag. 2013, 77, 1449-1458. [CrossRef]

10. Dugger, K.M.; Forsman, E.D.; Franklin, A.B.; Davis, R.J.; White, G.C.; Schwarz, C.J.; Burnham, K.P.; Nichols, J.D.; Hines, J.E.; Yackulic, C.B.; et al. The effects of habitat, climate, and Barred Owls on long-term demography of Northern Spotted Owls. Condor 2016, 118, 57-116. [CrossRef]

11. Schofield, L.N.; Eyes, S.A.; Siegel, R.B.; Stock, S.L. Habitat selection by Spotted Owls after a megafire in Yosemite National Park. For. Ecol. Manag. 2020, 478, 118511. [CrossRef]

12. USFWS. 12-Month Finding for the California Spotted Owl; U.S. Fish and Wildlife Service: Washington, DC, USA, 2019.

13. Verner, J.; McKelvey, K.S.; Noon, B.R.; Gutiérrez, R.J.; Gould, G.I., Jr.; Beck, T.W. The California Spotted Owl: A Technical Assessment of Its Current Status; General Technical Report PSW-133; U.S. Department of Agriculture Forest Service: Berkeley, CA, USA, 1992.

14. Franklin, A.B.; Anderson, D.R.; Gutiérrez, R.J.; Burnham, K.P. Climate, habitat quality, and fitness in northern Spotted Owl populations in northwestern California. Ecol. Monogr. 2000, 70, 539-590. [CrossRef]

15. DellaSala, D.A.; Bond, M.L.; Hanson, C.T.; Hutto, R.L.; Odion, D.C. Complex early seral forests of the Sierra Nevada: What are they and how can they be managed for ecological integrity? Nat. Areas J. 2014, 34, 310-324. [CrossRef]

16. Bond, M.L.; Lee, D.E.; Siegel, R.B.; Ward, J.P., Jr. Habitat use and selection by California Spotted Owls in a postfire landscape. J. Wildl. Manag. 2009, 73, 1116-1124. [CrossRef]

17. Bond, M.L.; Bradley, C.; Lee, D.E. Foraging habitat selection by California Spotted Owls after forest fire in southern California. J. Wildl. Manag. 2016, 80, 1290-1300. [CrossRef] 
18. Eyes, S.A.; Roberts, S.L.; Johnson, M.D. California Spotted Owl (Strix occidentalis occidentalis) habitat use patterns in a burned landscape. Condor 2017, 119, 375-388. [CrossRef]

19. Jones, G.M.; Kramer, H.A.; Whitmore, S.A.; Berigan, W.J.; Tempel, D.J.; Wood, C.M.; Hobart, B.K.; Erker, T.; Atuo, F.A.; Pietrunti, N.F.; et al. Habitat selection by Spotted Owls after a megafire reflects their adaptation to historical frequent-fire regimes. Landsc. Ecol. 2020, 35, 1199-1213. [CrossRef]

20. Borchert, M.I.; Farr, D.P.; Rimbenieks-Negrete, M.A.; Pawlowski, M.N. Responses of small mammals to wildfire in a mixed conifer forest in the San Bernardino Mountains, California. Bull. South. Calif. Acad. Sci. 2014, 113, 81-95. [CrossRef]

21. Ganey, J.L.; Kyle, S.C.; Rawlinson, T.A.; Apprill, D.L.; Ward, J.P., Jr. Relative abundance of small mammals in nest core areas and burned wintering areas of Mexican Spotted Owls in the Sacramento Mountains, New Mexico. Wilson J. Ornithol. 2014, 126, 47-52. [CrossRef]

22. Hanson, C.T.; Bond, M.L.; Lee, D.E. Effects of post-fire logging on California Spotted Owl occupancy. Nat. Conserv. 2018, 24, 93-105. [CrossRef]

23. Lee, D.E. Spotted Owls and forest fire: A systematic review and meta-analysis of the evidence. Ecosphere 2018, 9, e02354. [CrossRef]

24. Lee, D.E. Spotted owls and forest fire: Reply. Ecosphere 2020, 11, e03310. [CrossRef]

25. Thompson, J.R.; Spies, T.A.; Ganio, L.M. Reburn severity in managed and unmanaged vegetation in a large wildfire. Proc. Natl. Acad. Sci. USA 2007, 104, 10743-10748. [CrossRef]

26. Cruz, M.G.; Alexander, M.E.; Dam, J.E. Using modeled surface and crown fire behavior characteristics to evaluate fuel treatment effectiveness: A caution. For. Sci. 2014, 60, 1000-1004. [CrossRef]

27. Bradley, C.M.; Hanson, C.T.; DellaSala, D.A. Does increased forest protection correspond to higher fire severity in frequent-fire forests of the western USA? Ecosphere 2016, 7, e01492. [CrossRef]

28. Zald, H.S.J.; Dunn, C.J. Severe fire weather and intensive forest management increase fire severity in a multi-ownership landscape. Ecol. Appl. 2018, 28, 1068-1080. [CrossRef] [PubMed]

29. Lee, D.E.; Bond, M.L. Previous year's reproductive state affects Spotted Owl site occupancy and reproduction responses to natural and anthropogenic disturbances. Condor 2015, 117, 307-319. [CrossRef]

30. Jenness, J.J.; Beier, P.; Ganey, J.L. Associations between forest fire and Mexican Spotted Owls. For. Sci. 2004, 50, 765-772.

31. Bond, M.L. The Heat is on: Spotted Owl and Wildfire. Online Reference Module in Earth. Systems and Environmental Sciences; Elsevier Press: Amsterdam, The Netherlands, 2016.

32. Clark, D.A.; Anthony, R.G.; Andrews, L.S. Survival rates of northern Spotted Owls in post-fire landscapes of southwest Oregon. J. Raptor Res. 2011, 45, 38-47. [CrossRef]

33. Clark, D.A.; Anthony, R.G.; Andrews, L.S. Relationship between wildfire, salvage logging, and occupancy of nesting territories by northern Spotted Owls. J. Wildl. Manag. 2013, 77, 672-688. [CrossRef]

34. Lee, D.E.; Bond, M.L.; Borchert, M.I.; Tanner, R. Influence of fire and salvage logging on site occupancy of Spotted Owls in the San Bernardino and San Jacinto mountains of southern California. J. Wildl. Manag. 2013, 77, 1327-1341. [CrossRef]

35. Tempel, D.J.; Gutiérrez, R.J.; Whitmore, S.A.; Reetz, M.J.; Stoelting, R.E.; Berigan, W.J.; Seamans, M.E.; Peery, M.Z. Effects of forest management on California Spotted Owls: Implications for reducing wildfire risk in fire-prone forests. Ecol. Appl. 2014, 24, 2089-2106. [CrossRef] [PubMed]

36. Comfort, E.J.; Clark, D.A.; Anthony, R.G.; Bailey, J.; Betts, M.G. Quantifying edges as gradients at multiple scales improves habitat selection models for northern Spotted Owl. Landsc. Ecol. 2016, 31, 1227-1240. [CrossRef]

37. Jones, G.M.; Gutiérrez, R.J.; Tempel, D.J.; Whitmore, S.A.; Berigan, W.J.; Peery, M.Z. Megafires: An emerging threat to old-forest species. Front. Ecol. Environ. 2016, 14, 300-306. [CrossRef]

38. Carey, A.B.; Horton, S.P.; Biswell, B.L. Northern Spotted Owls: Influence of prey base and landscape character. Ecol. Monogr. 1992, 62, 223-250. [CrossRef]

39. Carey, A.B.; Peeler, K.C. Spotted owls: Resource and space use in mosaic landscapes. J. Raptor Res. 1995, 29, $223-239$.

40. Rosenberg, D.K.; McKelvey, K.S. Estimation of habitat selection for central-place foraging animals. J. Wildl. Manag. 1999, 63, 1028-1038. [CrossRef]

41. Glenn, E.M.; Hansen, M.C.; Anthony, R.G. Spotted owl home range and habitat use in young forests of western Oregon. J. Wildl. Manag. 2004, 68, 33-50. [CrossRef]

42. Irwin, L.L.; Clark, L.A.; Rock, D.C.; Rock, S.L. Modeling foraging habitat of California Spotted Owls. J. Wildl. Manag. 2007, 71, 1183-1191. [CrossRef]

43. Irwin, L.L.; Rock, D.F.; Rock, S.C. Habitat selection by northern Spotted Owls in mixed-coniferous forests. J. Wildl. Manag. 2012, 76, 200-213. [CrossRef]

44. Irwin, L.L.; Rock, D.F.; Rock, S.C.; Heyerly, A.K.; Clark, L.A. Barred Owl effects on Spotted Owl Resource Selection: A metaanalysis. J. Wildl. Manag. 2020, 84, 96-117. [CrossRef]

45. van Wagtendonk, J.W.; Lutz, J.A. Fire regime attributes of wildland fires in Yosemite National Park, USA. Fire Ecol. 2007, 3, 34-52. [CrossRef]

46. Odion, D.C.; Hanson, C.T. Projecting impacts of fire management on a biodiversity indicator in the Sierra Nevada and Cascades, USA: The Black-backed Woodpecker. Open For. Sci. J. 2013, 6, 14-23. [CrossRef] 
47. Rockweit, J.T.; Franklin, A.B.; Carlson, P.C. Differential impacts of wildfire on the population dynamics of an old-forest species. Ecology 2017, 98, 1574-1582. [CrossRef] [PubMed]

48. DellaSala, D.A.; Hutto, R.L.; Hanson, C.T.; Bond, M.L.; Ingalsbee, T.; Odion, D.; Baker, W.L. Accomodating mixed-severity fire to restore and maintain ecosystem integrity with a focus on the Sierra Nevada of California, USA. Fire Ecol. 2017, 13, 148-171. [CrossRef]

49. Kramer, A.; Jones, G.M.; Whitmore, S.A.; Keane, J.J.; Atuo, F.A.; Dotters, B.P.; Sawyer, S.C.; Stock, S.L.; Gutiérrez, R.J.; Peery, M.Z. California Spotted Owl habitat selection in a fire-managed landscape suggests conservation benefit of restoring historical fire regimes. For. Ecol. Manag. 2021, 479, 118576. [CrossRef]

50. Gutiérrez, R.J.; Pritchard, J. Distribution, density, and age structure of Spotted Owls on two southern California habitat islands. Condor 1990, 92, 491-495. [CrossRef]

51. Gaines, W.L.; Strand, R.A.; Piper, S.D. Effects of the Hatchery complex fires on Northern Spotted Owls in the Eastern Washington Cascades. In Proceedings of the Fire Effects on Rare and Endangered Species and Habitats Conference, Coeur D'Alene, ID, USA, 13-16 November 1995; Greenlee, J.N., Ed.; International Association of Wildland Fire: Missoula, MT, USA, 1997.

52. King, G.M.; Bevis, K.R.; Rowe, M.A.; Hanson, E.E. Spotted owls use of habitat impacts by the 1994 fires on the Yakama Indian Reservation: Three years postfire. In Proceedings of the Second Fire Effects on Rare and Endangered Species Conference, Coeur D'Alene, ID, USA, 29 March-1 April 1998; International Association of Wildlife Fire: Missoula, MT, USA, 1998.

53. Keane, J.J.; Gallagher, C.V.; Gerrard, R.A.; Jehle, G.; Shaklee, P.A. California Spotted Owl Module: 2010 Annual Report; Pacific Southwest Research Station, U.S. Forest Service: Davis, CA, USA, 2010.

54. Carroll, M.S.; Findley, A.J.; Blatner, K.A.; Mendez, S.R.; Daniels, S.E.; Walker, G.B. Social Assessment for the Wenatchee National Forest Wildfires of 1997, 1994, Targeted Analysis for the Leavenworth, Entiat, and Chelan Ranger Districts; Gen. Tech. Rep. PNW-GTR-479; Pacific Northwest Research Station, U.S. Department of Agriculture, Forest Service: Portland, OR, USA, $2000 ;$ p. 114.

55. Roberts, S.L.; Van Wagtendonk, J.W.; Miles, A.K.; Kelt, D.A. Effects of fire on Spotted Owl site occupancy in a late-successional forest. Biol. Conserv. 2011, 144, 610-619. [CrossRef]

56. Lee, D.E.; Bond, M.L. Occupancy of California Spotted Owl sites following a large fire in the Sierra Nevada. Condor 2015, 117, 228-236. [CrossRef]

57. USFS. Revision of the Inyo, Sequoia, and Sierra National Forests Land Management Plans, Draft Environmental Impact Statement; U.S. Forest Service, Pacific Southwest Region: Vallejo, CA, USA, 2019; p. 172.

58. Jones, G.M.; Gutiérrez, R.J.; Kramer, H.A.; Tempe, D.J.; Berigan, W.J.; Whitmore, S.A.; Peery, M.Z. Megafire effects on Spotted Owls: Elucidation of a growing threat and a response to Hanson et al. (2018). Nat. Conserv. 2019, 37, 31-51. [CrossRef]

59. Peery, M.Z.; Jones, G.M.; Gutiérrez, R.J.; Redpath, S.M.; Franklin, A.B.; Simberloff, D.; Turner, M.G.; Radeloff, V.C.; White, G.C. The conundrum of agenda-driven science in conservation. Front. Ecol. Environ. 2019, 17, 80-82. [CrossRef]

60. Jones, G.M.; Gutierrez, R.J.; Block, W.M.; Carlson, P.C.; Comfort, E.J.; Cushman, S.A.; Davis, R.J.; Eyes, S.A.; Franklin, A.B.; Ganey, J.L.; et al. Spotted owls and forest fire: Comment. Ecosphere 2020, 11, e03312. [CrossRef] 